\title{
Wari Women as symbols of power; and a case for client states
}

\author{
Frank M. Meddens
}

\begin{abstract}
This paper explores the characteristics of the expansion of the Wari empire. It reviews the evidence across the Andean region where the data for the relationship of the imperial elite with local ruling hierarchies is demonstrably varied. Assorted strategies pragmatically deployed by Wari served to exert its control and reflect a client state approach to its growth. The political basis for its relationship with the local elites is considered based on polygamous marriage structures and marriage alliances arranged between the imperial ruling circle and the regional chiefs, thereby creating kin structures with inequal duties and obligations of the regional polities with the imperial centre. This model is derived from Late Horizon ethnohistorical sources and tested in the available archaeological data.
\end{abstract}

Keywords: Ancestor(s), elite women, kin(ship), gifting, Inca, Wari

\section{Resumen}

MUJERES WARI, SÍMBOLOS DE PODER; UN CASO PARA ESTADOS SATÉLITE

Este artículo explora las características de la expansión del imperio Wari. Revisa la evidencia en la región andina donde los datos de la relación de la élite imperial con las jerarquías gobernantes locales son demostrablemente variados. Varias estrategias implementadas pragmáticamente por Wari sirvieron para ejercer su control y reflejan un enfoque de estado cliente para su crecimiento. La base política de su relación con las élites locales se considera basada en estructuras matrimoniales polígamas y alianzas matrimoniales arregladas entre el círculo gobernante imperial y los kurakas regionales, creando así estructuras de parentesco con deberes y obligaciones desiguales de las etnias regionales con el centro imperial. Este modelo se deriva de fuentes etnohistóricas de Horizonte Tardío, y se comprueba en los datos arqueológicos disponibles.

Palabras clave: Ancestros, mujeres elite, familiares / parentesco, regalo / regalar, Inca, Wari

Frank M. Meddens• University of Reading, email: frank.meddens@googlemail.com (D) https://orcid.org/0000-0002-7210-7101 


\section{Introduction}

Wari was first recognised as a cultural phenomenon separate from Tiahuanaco by Julio C. Tello (1931) and first styled as an empire by Lumbreras (1974). William Isbell and Katharina Schreiber in their 1978 publication considered Wari to have been a pristine state which 'arose through evolutionary processes'. They characterised the state as a system of government which held a monopoly on the right to use force in the execution of decisions and in the maintenance of order; defended its territory and sovereignty, and administered its public affairs through a hierarchy of officials (1978, 372). Ruth Shady subsequently interpreted Wari as operating on trade and exchange mechanisms (Shady 1988a,b). More recently Justin Jennings proposed a globalisation model for the expansion of the Wari state (Jennings 2010; 2015, 200-1).

Over time it became evident that, from the archaeological point of view, the Wari state exhibits significant variation over its various regions. Kathy Schreiber noted that it operated by means of a "diversity of strategies of consolidation, a mosaic of control, not direct control in every valley" $(1992,276)$. Moreover, multiple parallels between the Wari and Inca mechanisms of state control have been recognized (Makowski and Giersz 2016). Here it is argued that for the elites, polygamous marriage, marriage alliances and kin relationships formed the basis for maintaining and replicating power structures and reciprocal affiliations between powerful state elites. This paper proposes a client state model for much of the expansion of the Wari state and outlines the role of the gifting and exchange of women in establishing inter-elite kin obligations and duties in the management and administration of the empire.

\section{The Site of Huari}

The site of Huari is situated c. $26 \mathrm{~km}$ by road from the present-day city of Ayacucho. Huari represents what would have been the capital of the Wari empire. It grew out of a large Early Intermediate Period Huarpa settlement with its ceremonial core extending over an area of some six square $\mathrm{km}$. The site developed over time, with parts of it being modified and rebuilt as requirements changed. The remains of the ancient city form part of a typical complex, urban, archaeological sequence, demonstrating that the city remained successful over a prolonged period of time, with superimposed and intercutting archaeological features at its core extending to depths of 4 to $20 \mathrm{~m}$ below the present-day ground surface. Along the north-western side of what would have been the administrative, elite residential and ritual nucleus of the site is the Vegachayoc Moqo sector, formed of a large trapezoidal enclosure, with a series of niched chambers along its sides, and a substantial D-shaped temple structure with a further D-shaped temple, situated immediately to the northeast, at its base (Bragayrac 1991). To the south, the Monjachayoc sector has a further D-shaped temple along its western margin. Within 
the complex itself, there are two more large D-shaped structures, each featuring a major multiple-level cut stone mausoleum. The two multiple-level cut stone mausoleum shaft tomb structures measure c. $12 \times 6 \mathrm{~m}$ in plan and were built across 4 floor levels. Each level contains a large number of rectangular cell-like chambers constructed of dressed stone (Perez Calderon 1999) and the most recently uncovered example is constructed of extremely finely-cut ashlar walling. Two circular shafts situated approximately one above the other and separated by the third-floor level are present. The first one measures c. $6 \mathrm{~m}$ in depth, the second c. $5 \mathrm{~m}$ in depth, and the lower one appears to have held the remains of a member of the principal elite at its base. The foundation level of these tombs is at about $20 \mathrm{~m}$ below the surface. Considering the construction efforts manifest in the two tombs and the associated artefactual remains, it is likely that these tombs would have belonged to the rulers of the empire. Around $300 \mathrm{~m}$ southeast, in the Moraduchayoc area of the site, remnants of two semi-subterranean temple structures have been uncovered, similar to those known from the site of Tiahuanaco in Bolivia. Superimposed on top of these remains are a number of galleried patios in two enclosures, off-set on different alignments to each other (Isbell et al 1991; Spickard 1983). Further to the south-east is the Cheqo Wasi sector, where another D-shaped temple as well as numerous megalithic chamber tombs have been found (Benavides 1991). Many smaller cut stone megalithic chamber tombs are associated with the principal zone of the site, comprising the Vegachayoc Moqo, Monjachayoc, and Cheqo Wasi sectors across a distance of c. $1 \mathrm{~km}$ (Schreiber 2012).

Huari extends in all directions from its elite centre covering an estimated total area of around 600 ha. Evidence suggests that parts of the site were inhabited by craft specialists, such as ones working in turquoise, as well as sectors where residents from distant parts of the empire may have been dwelling, for example from the Cajamarca region (Bennett 1953).

In addition, elements of infrastructure essential to the functioning of a large urban centre have been identified. These include parts of its water supply system, known to have included segments of a large aqueduct, Pampachacra, a major canal which was fed by the glacial waters of Rasuwillca and four huge reservoirs at Tawaqocha (Perez Calderon 1999, 89-92).

\section{Wari State Architecture and its associated archaeology}

The model for the Wari state is formulated around its administrative architecture, which comprises rectangular enclosure compounds argued to have served as administrative and elite complexes, and found at the site of Huari itself. These have been observed as having been duplicated at sites such as Cerro Baúl (Moseley et al 1991), Jincamocco (Schreiber 1992), Pikillacta (McEwan 2005), Viracochapampa (Topic 1986, 1991), Huaro (Glowacki 2002), Raqchi (Sillar et al. 2013) 
and others. These compounds are relatively modular rectangular enclosures subdivided into squarish complexes with rectangular galleries around the perimeter and with open patios in the central space.

A second architectural canon found at Wari state-related sites involves the D-shaped temple form, which besides at Huari has been found at Conchopata, on the outskirts of the city of Ayacucho, Leqles Pata in the Sondondo valley (Schreiber 2004), Yako in the Chicha-Soras valley (Meddens and Cook 2000), Honcopampa in Ancash (Isbell 1989), and Espiritu Pampa in the Vilcabamba area, among others. These D-shaped structures comprise partially circular edifices with a single flattened side which centrally placed has a single entrance, and which tend to have a series of large niches in the circular wall facing the interior and the entrance. The shaped structure appears to have a role related to the realm of the dead (Meddens and Cook 2000). Some antecedents to these architectural traditions can be found in the La Libertad area for the rectangular compound form such as at Marca Huamachuco (Topic 1986; 1991), as well as at Yayno in Ancash (Lau 2011, 70-74).

The Huarpa Valley, immediately northwest of Huari, and the Ayacucho valley includes the rectangular-enclosure site of Azangaro, which is likely to have served as the local Wari administrative and elite compound (Anders 1986). The Huanta area has numerous earlier Huarpa-period sites, as well as at least 14 Wari lower order occupation and funerary sites, distributed throughout the valley, mostly situated on relatively level, lower-valley, river terraces and middle-valley slopes (Landeo Lappa 2010).

The site of Jincamocco in the Sondondo Valley in the southwest of the Department of Ayacucho constitutes a moderately sized rectangular enclosure compound while there are three smaller Wari compound sites in the area. The valley has a further seven Middle-Horizon villages and two hamlet-sized sites (Schreiber 1987), as a well as an important sacred precinct featuring a D-shaped temple-type structure at Leqles Pata, a site situated in a convenient position to control access to two local huacas (Schreiber 2004).

The neighbouring Chicha Soras Valley lacks the characteristic rectangular compound-type site but includes a gallery-and-patio complex at Chiqna Jota and the site of Yako which features ruins of a D-shaped temple building. There are seven Middle Horizon occupation sites in the valley, all of which are situated on relatively level valley slopes. There is a cave site on the valley's western margin with a tomb structure comprising a number of small cell-like rooms, some of which have rectangular windows. The tomb overlooks the valley to the east and north, with a view downstream the Chicha Soras river (Mallco Huarcaya 2013; Mallco Huarcaya and Angulo Paredes 2016; Meddens 1985; 1991; Meddens and Cook 2000; Meddens and Branch 2010).

There is evidence for disruption in the archaeological sequence with the site of Yako being abandoned at the close of Middle Horizon epoch 2, at the time when the Wari state loses its imperial power. However, the principal centre of Chiqna Jota 
continues to be occupied, and a definable elite endured to manifestly express its dominance over the local population until well into the Late Intermediate Period, at which time there is a further dislocation in the sequence prior to the Late Horizon intrusion of the Inca state (Meddens and Vivanco 2018).

Viracochapampa is situated near Huamachuco in the Department of La Libertad on a flat plain, over $3000 \mathrm{~m}$ ASL. The site comprises a large rectangular Wari administrative compound with multiple patio-and-gallery sections, which do not appear to have been completed before the site was abandoned during Middle Horizon epoch 2 (Topic and Topic 2000).

Some of the local polities from the Cajamarca region appear to have gained influence at the time of Wari expansion, as demonstrated by an increased reach of Cajamarca ceramics along the western slopes of the cordillera. Late Cajamarca style ceramics have been found at the capital site of Huari itself (Bennett 1953) and identified at other important Wari sites, including Azangaro, Cerro Baúl, Pikillacta and Huaro. In the Cajamarca region, fine quality Wari style items have also been identified (Toohey 2011). Jason Toohey proposes increased autonomy for the Cajamarca region and the local polities, following the decline of Wari (Toohey 2011).

In the Ancash area, sites with a Wari signature have been recognised, including Honcopampa and possibly Keushu, where patio-and-gallery complexes, as well as D-shaped structures have been recognised (Isbell 1989).

South east of Cuzco there is the mayor Wari administrative complex of Pikillacta, situated immediately above a lake. It is the largest known Wari site, besides Huari itself, comprising rectangular compounds with galleried patios. The site appears imposed on the landscape ignoring elements of the underlying topography. Parts of Pikillacta were used for ritual feasting. It appears to have functioned as the principal administrative site for the region (McEwan 2005).

The Middle Horizon Wari complexes identified in the Huaro valley east of Pikillacta include the looted remains of elite shaft tombs at Batán Urqu (Zapata 1997), a stepped pyramid type structure at Kanincuna, comparable to the Akapana temple at Tiahuanacu (Glowacki and Zapata 1998; Kolata 1993, 104-106), and galleried patio structures at Qoripata (Glowacki 2002). The excavated architectural characteristics of the Qoripata site in the Huaro valley near Cuzco have been compared to those observed at the Moraduchayoc sector of the site of Huari (Glowacki 2002; Glowacki and McEwan 2001).

At the end of Middle Horizon epoch 2, the Huaro valley sites and Pikillacta are abandoned but an elite continues to be influential with large sites, such as Chokepukio having elite and sacred sectors (McEwan et al. 2002) and probably Cuzco itself being established on level mid-valley lands and rising to dominance (Farringdon 2013; McEwan et al. 2002).

East of Huari, and on the east side of the cordillera, on the slopes descending toward the tropical rainforests of the Amazon basin in the Vilcabamba region, 
the site of Espiritu Pampa has revealed impressive Wari remains. At this location, long known for its associations with the last stand of the Incas against the Spanish colonial power, and for being the residence of the last Inca kings of the early colonial neo-Inca state, four D-shaped Wari temple structures and a rich elite tomb have been uncovered (Fonseca Santa Cruz and Bauer 2013). The principal tomb included fragmentary remains of a single male individual accompanied by a large silver pectoral, a silver mask, two silver decorated staffs, two gold bracelets, as well as hundreds of thin silver disks, which would have been attached to the clothing of the individual, as well as many greenstone beads. A further 11 tombs were found across the complex (Fonseca Santa Cruz and Bauer 2013). A series of irregular shaped agglutinated chambers and galleries filled much of the space between the three largest $\mathrm{D}$-shaped structures, while the fourth smaller D-shaped building comprised a later replacement of its predecessor, constructed inside the outline of the southwest-most D-shaped structure (Fonseca Santa Cruz and Bauer 2013).

In the Cotahuasi valley in the department of Arequipa, the Middle Horizon resident population expands with earlier settlements continuing to be occupied, growing in size, and 8 new habitation sites being established (Jennings 2015a, 2938). Tenahaha was founded during the Middle Horizon and abandoned by its end. This site is distinct from what came before and after and appears to have fulfilled an important funerary function. Similarly to other contemporary sites in the area, it does not follow Wari cultural tenets, as it would be expected to, were it under direct Wari control (Jennings and Yepez 2015, 15, 90-2).

Cerro Baúl in the Moquegua Valley, situated in a dominant and highly defendable location, includes multiple galleried patio spaces and evidence for organised production of maize beer and its use in ritualised feasting. The valley has a number of contemporary Tiahuanaco settlements and the two rival states appear to have been in direct competition in this basin (Moseley et al 1991; Nash 2011).

On the south coast in the Department of Arequipa, the site of Sonay constitutes a small Wari facility situated in the Camana Valley (Glowacki and Malpass 2003; Malpass et al. 1997).

The Nasca area is of particular interest to the development of Wari, as significant interaction between the Nasca drainage and the Ayacucho area in the later Early Intermediate Period and in the early Middle Horizon Period is manifest in the contemporary ceramic styles from the Ayacucho valley and the Early Intermediate Period Huarpa ceramics from Ayacucho, including late Nasca style iconography. Nasca 8 (equivalent of the Loro style after the type site of Huaca del Loro) and Nasca 9 style ceramics from the Nasca area resemble Chakipampa style pottery.

Wari influence and presence in the Nasca area was initially thought to have been significant. The site of Pacheco in the lower-middle Nasca valley has been largely destroyed, but it may have been a Wari administrative site architecturally comparable to other such Wari examples. It measured around $300 \mathrm{~m}$ across and had 
evidence for structural remains (Menzel 1964, 23; Tello 2002, 9). A major formal offering deposit has been found at Pacheco. It comprised of a large number of Robles Moqo style oversize vessels (first identified by Tello at Conchopata) including very large tumblers and urns as well as face neck jars and ceramics modelled in the shape of camelids (Menzel 1964, 22). These ceramics had been intentionally broken in situ and interred in conjoining adobe chambers measuring about 2 by 1.50 meters, by about 2 meters deep (Menzel 1964, 23-25; Tello 2002, 203-207).

Numerous burials from the Nasca area have produced high quality Wari style ceramics, while substantial systematic surveys by Katherina Schreiber and her students demonstrated that actual Wari sites in the Nasca drainage are rare, with its presence being limited to two or three cemeteries which include Wari-style tomb structures (Edwards and Schreiber 2014, 218). A large Wari administrative site comprising a substantial planned rectilinear enclosure measuring c. 150 x $150 \mathrm{~m}$, called Incawasi is present in the Uchuymarca area in the upper Aja valley. Evidence for a Wari component being present on the site of Calvario, a local Nasca site with origins in the Early Intermediate Period, have been further identified here.

Extensive hillside terracing, a Wari cemetery and the small Wari rectangular enclosure site of Pataraya constructed of double faced, rubble filled masonry walling, are situated in the upper Tierras Blancas Valley. Ancient roads connect the Pataraya site with Incawasi (Edwards and Schreiber 2014, 218-231). The principal Pataraya compound is square in plan and measures c. $20 \times 20 \mathrm{~m}$. There are two later rectangular annexes which abut the main compound on its north and east sides. Excavations revealed a number of activity areas with food preparation and processing taking place in the galleries and patio on the southeast side of the complex. The northwest galleries and patio served as the elite residential area and the southwestern patio and galleries performed a role in public activities involving feasting. ${ }^{14} \mathrm{C}$ dates for the site fall between cal. A.D. 672 and 990. Prior to its abandonment the site appears to have been carefully secured and sealed (Edwards and Schreiber 2014, 218-231).

Later Late Intermediate Period Nasca sites in the upper valley areas of the drainage witness a shift to more defensible locations (Schreiber 2005, 246). The site of La Marcha has a substantial local Middle Horizon component (Kerchusky 2018), While the Late Intermediate Period sites of Pajonal Alto and La Tiza include Middle Horizon components (Conlee 2010).

Huaca del Loro was the primary centre of the Las Trancas Valley which originated in the Early Intermediate Period and continued to be occupied during the Middle Horizon. Zorropata, also situated in the Las Trancas Valley, constitutes a lower second order sized settlement. Huaca del Loro includes habitation, ceremonial and funerary sectors. Demographic shifts appear to have been associated with the Middle Horizon period for the Nasca region with large scale relocation of local settlements from the Nasca and Taruga Valleys to the Las Trancas Valley (Kerchusky 2018). 
In the lower Pisco valley, the site of Maymi is situated on the north bank of the Pisco river on an ancient river terrace, facing the monumental Formative site of Chongos and in close proximity to the irrigation canal intakes for the lower Pisco valley. The site measures c. $430 \times 120 \mathrm{~m}$ (approximately 5 ha). The location offers an impressive view over the lower valley. It was occupied continuously from the Formative to the Late Intermediate Period. Evidence for quincha (cane and mud) constructions is widespread. The site includes material characteristic of pottery production, similar in this respect to pottery production evidence at the site of Conchopata in Ayacucho (Isbell and Cook 2002). Adobe-built foundations are associated with the Wari material presence on site. Adobes in a range of different shapes (cylindrical, semi-cylindrical, cuboid, rectangular and triangular) are present as are offerings comprising unfired clay figurines and vessels wrapped in cotton, which were identified in material associated with Nasca 8, 9, Robles Moqo, and Chakipampa pottery fragments. The northern sector of the site lacks habitation remains, but a wall constructed of adobes and quincha on adobe foundations formed a likely rectangular structure with a narrow chamber along its eastern side. This structure was coupled with a series of pits in its north-eastern corner in which large numbers of very fine elite wares had been placed and expertly broken (Anders 1986). The presence of Robles Moqo material in an offering context is also known from the contemporary Ayacucho Conchopata site (Isbell and Cook 2002; Menzel 1964).

Late Intermediate Period Nasca settlements were relocated and reorganized with features characteristic of a relatively high degree of socio-political and economic complexity with clearly definable elite habitation components. These sites include evidence for participation in long distance exchange networks (camelid fibre, obsidian, and spondylus).

For the Lurin, Rimac and Chillon valleys, the site of Socos in the Chillon has been identified as a Wari type enclosure (Malpass et al 1997). Pachacamac in the lower Lurin valley on the coast and Cajamarquila in the Jicamarca Valley, a tributary to the Rimac, have produced significant Wari burial and offering evidence but no associated monumental architecture (Makowski and Giersz 2016).

Castillo de Huarmey comprises the largest known Middle-Horizon site on the North coast, measuring some $45 \mathrm{ha}$ and situated some $4 \mathrm{~km}$ from the sea in the Huarmey Valley on a large rocky promontory. The monumental core of the site is surrounded by cemeteries and dispersed residential sectors. The monumental core was constructed in a number of phases and includes various platforms with construction materials including adobes, stone, timber and painted plaster. Its remains measure some $150 \times 70 \mathrm{~m}$ comprising a number of multiple-floor funerary mausolea and chullpa type structures constructed over a period of time, remodelled and superimposed. Dedicatory offerings of people and camelids have been identified. Craft production areas and residential quarters of Middle Horizon Period have also been uncovered. An important mausoleum with an intact antechamber, funerary 
chamber and room dedicated to the posthumous cult of the dead, has been found. The site notably continued to be occupied during the late Intermediate Period and the Late Horizon and maintained an association with the local elite hierarchy (Giersz and Makowski 2014).

\section{Wari expansion, demographics, and militarism}

The success of Wari expansion has been attributed to an aggressive military strategy (Isbell 1977, 2010; Isbell et al 1991; Isbell and Schreiber 1978; Tantaleán 2014). The importance of a warrior element to the Wari culture can be recognised in the iconographic representation of warriors on some of its ceramics, which depict, for example, men equipped with axes, bows and arrows, etc. standing on what appear to be reed boats. Similarly, there are warrior images in an offering deposit found in front of the threshold of the eastern gate of Pikillacta. These include cast copper alloy figures, as well as repoussé sheet metal figurines, spondylus and lapis lazuli examples, and there are additionally a number of figurines representing bound prisoners (Arriola Tuni and Tesar 2011).

The distribution of Wari sites where Wari architectural layouts and details can be identified and where Wari artefact assemblages have been found is largely found on flat and level terrain. Though these sites commonly have high enclosure walls, they do not appear to be situated with warfare and defence as an important characteristic in mind. There are exceptions, though, such as Cerro Baúl, for example, which sits on a flat plateau on top of a mountain summit, which held a strategic position overlooking the surrounding valley. In the Moquegua valley, Cerro Baúl and other Wari sites are found in close proximity to Tiahuanaco sites which, as presenting a rival and competing actor, explains the need for a Wari defensive posture here (Moseley et al 1991). As in the Moquegua valley, the spheres of interaction of the Wari and Tiahuanaco states converged, their competition in the area has been demonstrated to have contributed to the loss of hegemony over this region by both polities (Williams 2002). For the Moquegua area, following the loss of central Wari control, during the Late Intermediate Period Tumilaca phase, the local Moquegua elite was able to continue to operate retaining its hierarchical dominance. They maintained a suite of stylistic symbols in the local ceramic style clearly inspired by the preceding Wari iconography (Sharratt 2019).

Wari sites have their individual and distinct character which is considered to be the result of local requirements and architectural traditions. The fact that they conform to certain standard planning outlines and construction details is attributed to the requirements of the state with respect to centralized planning efficiencies, and the need for emblematic state symbolism expressed in the state architecture (Spickard 1983; Schreiber 1992; Jennings and Yepez 2001, 147). 


\section{Equivalencies of Wari state mechanisms and ideology with late Inca models}

It has been proposed that Wari's ideological foundations are manifest and can be recognised in Late Horizon Inca traditions (Glowacki and Malpass 2003; Makowski and Giersz 2016, 20-1). Mary Glowacki and Michael Malpass make a case for Wari state ideology being rooted in notions related to the circulation of water in natural systems, the worship of water sources, the presence of mountains and huacas in the landscape, and ancestor worship (Glowacki and Malpass 2003). Similarly, they and Makowski and Giersz reference the importance of landscape oracles to the Wari, such as is likely to have been the case with Pachacamac (Glowacki and Malpass 2003; Makowski and Giersz 2016, 20). Similarities and equivalence of aspects of Inca and Wari ideology continue to be revealed in archaeological contexts, as in the identification of stone monoliths as a signifier of stone ancestors or counterparts or as sacred stones as similarly known from the Inca, which have been identified in a Wari context at Conchopata. Here eight modified elongated stones were found placed upright at the base of a pit or cylindrical stone-lined cist, inside a D-shaped temple structure (Cook 2015, 295-326; Meddens et al. 2010, 89-90). That ancestor worship formed an important aspect of the Wari belief system is now the consensus amongst archaeologists (Isbell and Korpisaari 2015, 148; Topic and Topic 2000; Meddens and Branch 2010), although Isbell makes a distinction between ancestor worship and ancestor mummies as maintained by the Incas (Isbell and Korpisaari 2015, 148).

The Inca architectural form of a cancha enclosure could be and was used in a variety of different roles. This type of enclosure at Ollantaytambo (as elsewhere) represents a domestic unit (Protzen 1993), a place where people lived and prepared and ate food, whereas in the spatially similar enclosure of Coricancha in Cuzco, the space comprises a temple precinct (Bejar Navarro 1990). Whether it would have been possible to distinguish Coricancha from elite Inca residential space on the basis of archaeological data alone remains an open question. This example makes clear, however, that similarly planned architectural spaces in an Andean context may have radically different functions. Similarly, the Wari patio or open court complex with long narrow chambers or galleries is known to have served varied functions including formal ritual feasting in an administrative role (Cook and Glowacki 2003), while at Pataraya both food preparation and processing and elite residence functions have been identified (Edwards and Schreiber 2014), and at Conchopata they included a funerary role with burials being placed below the floors of rooms and patios (Isbell 2004, 6).

Near the base of an offering pit found at the east gate entrance to the Pikillacta site, a tapering $47 \mathrm{~cm}$ long bronze rod was found driven into the basal deposits. Similar rods were associated with the two turquoise figurines offerings from Pikillacta found in 1927 (Cook 1992). This find has been interpreted as manifesting Wari's physical and spiritual rights to the site (Arriola Tuni and Tesar 2011, 31-32). 
Such an interpretation would fit perfectly with one present in the Inca founding myths of Cuzco in which Manco Inca or Mama Huaco repeatedly drive a golden rod into the ground in order to select the site for the founding of Cuzco in the place where the rod sinks (Sarmiento de Gamboa 1988 [1572], 57-61), further reinforcing the notion of the Inca state's co-opting of many aspects of not only general state organisational structures, but indeed specific features of the cosmology and ideology of its Wari predecessor. The notion that Mama Huaco, one of the female mythical ancestors would have been instrumental in this act is of particular interest as it links claims of territoriality with the female gender.

\section{Client state structure}

A client state model in so far as it applies to Middle Horizon Peru and its expansive Wari empire is rooted in notions of the Wari state electing to adopt least resistance and pragmatism in the repertoire of strategies it deployed in its successful growth. An expanding empire will seek to minimise expenditure in conquest wherever possible (Schreiber 1992). Evidently it would need a strong ideological base as well as a successful and mighty military arm, which served to demonstrate its will and resolve to deploy power as well as signify its success and manifest the favour it received from the world of the supernatural. Where achievable it would seek to achieve its aims of expansion by coercion and persuasion. This would be most easily achieved by convincing the controlling elite of any territory which the empire sought to assimilate of the benefits to its privileged leadership of incorporation (Makowski and Giersz 2016, 30-1). While the empire was successfully expanding, such benefits would be easily recognised and the symbols of incorporation could be adopted in architecture, dress and artefacts, while kin ties with the imperial ruling class could be formalised and bring about taxation rights and tribute obligations. Such an approach would afford the empire flexibility in its cost of expansion. The manner in which such an empire would exhibit itself archaeologically would be one in which its presence would be most clearly visible in the households of the top tier of the elite, with little of its characteristic patterning filtering down to the commoner communities outside of the upper tier settlements. In contrast occasional islands of highly structured imperial administrative sites would be found in areas where such direct control was essential for the coherence of the state. A pattern like this may be recognisable in the Cusco area with Pikillacta and Huaro (McEwan 2005; Glowacki 2002), typical of direct control of the state, while rural hinterland village sites, such as Akawillay on the Pampa de Anta northwest of Cusco, demonstrate very limited penetration of Wari traditions (Bélisle 2015). A client state relationship may be characterised by patterning such as that observed in Ancash, the lower Pisco valley, the Lurin, Rimac and Chillon valleys and elsewhere, where the evidence suggests voluntary acceptance of a limited set of concepts and material culture. 


\section{State power, women exchange and gifting}

Within the Late Horizon Inca power arrangements, the top tier of the elite of the dominant state established a power structure in which lower elites had obligations to the upper tier of leaders as a result of kinship rules which would be formed by means of the exchange of women and establishment of marriage structures. This being reinforced by unequal gift giving and acceptance of such gifts in support of the benefactor receiving unequal tribute obligations from the recipient in exchange (Hernandez Astete 2012, 220-235, passim).

Within Andean ideological frameworks the dual male / female gender construct is fundamental to the operation of all institutions. The Wari state has been interpreted as a 'first generation state' with variable levels of control across the region that it dominated with core areas of control, isolated colonies and regions across which it had little or no presence (Fonseca Santa Cruz and Bauer 2013, 112). It is argued here that the archaeological evidence could alternatively reflect a different model.

The middle Horizon Wari power structures can be seen, to a large extent, to be paralleled in the Late Horizon Inca state structure (Makowski and Giersz 2016). The latter was founded on the exchange and gifting of women between and to ruling elites. The kinship structure and exchange obligations linked to these resulted in perceived notions of elite generosity. In this context women held significant positions of power. They may have been active agents in the process of gifting, and certainly would have continued to play an active role in a position of authority in their elite married roles. This would have allowed such married women to be involved in developing the relationship between client states, and between these states and the central authority of Wari.

\section{The Inca State and the gifting of Women}

The power structure the Inca derived from their kinship system to a significant extent resulted from the numbers of kin the ruling authority could call on. This would have depended in part on the number of wives the ruler had, through whom he could lay claim to kinship obligations of their ethnic groups of origin and the labour obligations these were subject to. Particularly, Guaman Poma's enumeration of the numbers of wives which various social categories of men could marry is illuminating in this context. Each of these ranked individuals had the administrative responsibility over larger and larger groups and each of these ranks was allocated increasingly larger numbers of wives: with principal kurakas having 50 wives, a huaranga kuraka (a ruler of 1000 domestic units or families) having 15, a pachaca camachicoc (responsible for 100 families) having 8 wives, a male mitimae having two and a soldier one wife (Guaman Poma 1980 [1616], vol 1, 189[191] 164). Clearly, the Inca rulers, being the highest-ranking males within the state structure, 
merited the largest number of wives, including wives from his lineage, among whom were the 'legitimate' highest classed sister category, who could become Coya , with lower-ranking wives consisting of those who came from the provincial class of kurakas, thereby producing direct kin links, obligations and rights with these groups. Garcilaso states unequivocally that marriage among his lineage was directly arranged by the Inca among youngsters in the correct age category, every one or two years, with the Inca selecting who was to marry who (Garcilaso 1723 [1609], Lib IV Cap. VIII, 112). In the provinces, selections were made by delegated Inca governors and kurakas amongst the relevant age category for each community among the commoners, with such marriages therefore being administered, arranged and approved by the Inca (Garcilaso 1723 [1609], Lib IV, Cap. VIII, 112-113). Guaman Poma states that the Inca distributed women in the month of November (Guaman Poma 1980 [1616], vol 1, 231). Garcilaso erroneously attributes the characteristics of a contemporary Spanish nun following a vow of chastity to the aclla category of women in Tawantinsuyu (Garcilaso 1723 [1609], Lib IV, Cap. III-V, 107-111). He creates a further separate pool of women, the daughters of captains and kurakas, whom the Inca deploys in the gifting of women to ranked individuals of the ruling Inca elite and provincial leaders and rulers, who are to be incorporated in the Inca state's kin structures (Garcilaso 1723 [1609], Lib IV, Cap. VI, 111). The category of Captains, as referenced by Garcilaso and other contemporary chroniclers, refers to high ranked males of the Inca elite lineage or Incas by privilege with the aclla women being the group amongst whom the Inca could have identified and selected the women to be passed for marriage to Inca military leaders, ethnic lords and relevant lower male elites (Silverblatt 1987, 87-88).

The power of elite women in the context of the prehispanic state is evident. The principal 'legitimate' wife who was the female spouse in the brother-sister marriage, forming the royal divine couple of the son of the sun and the daughter of the moon, would have constituted the highest-ranking woman in the Inca empire. The Coya, transmitted the royal line and rights to the throne (Zevallos 2018, 56). In some versions of the foundation myth of the Inca lineage, Manco Capac married his mother rather than sister (Idem 2018). The interweaving of some of the kin terminology, in which the Inca Coya is referred to as the mother of the Inca king rather than his sister, is evident from several other sources (Hernandez Astete 2012). Some of the charges, duties and powers of the Inca Coya get presented in certain chronicle sources as exemplifying the essentially demonic nature of this potent female character. This in particular concerns the sacred aspects of the coya's duties, mainly with respect to agriculture, crops and fertility and, for certain forms of Christian religious thinking, was already founded in a viewpoint which perceived womanhood and sexuality as being of very dubious nature (Zevallos 2018, 58). Mama Huaco as the first coya is portrayed in the founding myth as a councillor to the Inca king and as a warrior queen (idem 2018). 
The Sapa Inca was in a position which enabled him to distribute marriageable women from other segments of the elite (Garcilaso de la Vega 1723 [1609], Lib IV, Cap. III-V, 107-111). The aclla huasi (house of the chosen women), besides facilitating the production of particular categories of textiles and alcoholic beverages for use of the state, served as repositories for Paco Aclla, women reserved to be married to kurakas and other important male members of the elite (Rostworowski $1988,11)$. By being the one giving these women in marriage, the Inca would create and consolidate the network of kin links for himself and thereby generate the related obligations and duties. Polygamy for the elite was thereby a given establishing a sustainable form of propagating power and reciprocity.

Within the Inca elite the Inca's ability to distribute acllas or chosen women as spouses to subject rulers and subordinate elite men within the administration, while secondary wives facilitated the expansion of, and thereby enrichment of elite households. For both the giver and receiver of wives this served to increase the network of political, economic, and ritual relationships (Silverblatt 1987, 87-90). Albeit that the nature of such marriage alliances was in real terms an unequal one in its expression of reciprocal obligations and duties, it was indeed an instrument embedded in Inca strategies of conquest (idem 90-94). In fact, the gifting of women to lower order kurakas and exchanges of women with senior elite was critical to the coherence of the state (Hernandez Astete 2012, 220-235, passim) and its system of government (Silverblatt 1987, 89).

In the Inca kinship terminology terms for father and father's brother were equivalent as these were for mother and mother's sister. This with a patrilineal extending of the terminology, so that father's brother son would be the same term ( $k a k a)$ as father's brother. While terms for sister and brother varied, depending on whether it was sister addressing brother or sister, or brother addressing brother or sister, with these terms being extended to cousins (Lounsbury 1978, 991-3).

In the Inca world view, the ideal model of marriage was when marital partners came from the same ayllu. In Tawantinsuyu the ayllu was an endogamous institution, the ayllu being the basic community group whose members claimed origin in a common ancestor. Furthermore, the model marriage would involve a reciprocal exchange between the groom's and bride's kin groups preferably with the bride's brother marrying the groom's sister, in the form of sister exchange. (Isbell 1997, 273-281; Silverblatt 1987, 132; Zuidema 1977; 1990).

As noted, sister exchange in an Andean context resulted in the establishment of kin relations which involved defined duties and obligations to the in-laws. Within the Andean hierarchical elite structures, such responsibilities and commitments would have been asymmetrical in nature.

Within the upper strata of the Inca elite, the pool of women available for sister exchanges comprised groups of half-sisters made up of daughters of secondary wives of the ancestral Sapa Inca. In this framework too, one can appreciate that 
in terms of wealth, a rich person in the Andes was rich in kin, and by having sisters who could be married off, this wealth could be multiplied.

DNA analysis of 27 individuals of Late Horizon date from several chullpa tomb complexes from the Late Horizon site of Tompullo 2 in Arequipa confirmed that the genetic makeup of the late prehispanic population represented here was of similar composition to that of the present-day local population, confirming continuity of descent of this population. In addition, there was a marked level of relatedness within and among tomb groups, although the degree of kinship within tomb groups proved higher. Also, within two tomb groups all males were interrelated across different generations and patrilineal family groups and members of each family group were buried in the same grave. The observed pattern is not inconsistent with that of the model of sister exchange proposed by Isbell and others for the Inca population (Baca et al 2012; Isbell 1997, 273-281; Silverblatt 1987; Zuidema 1977; 1990). As noted above, in this model it is presumed that the marriage couple come from within the same ayllu and that the groom's sister marries the bride's brother (Isbell 1997). It is therefore the wife who translocates from her original place of residence to that of the groom (Isbell 1997, 273-281). Isotopic data from Late Horizon funerary contexts from Chokepukio also appear to support the Late Horizon model of women migrating for marriage purposes (Andrushko, et al. 2009, 69).

\section{Wari Women}

The fact that married status was of relevance for Wari women is confirmed by evidence from burials at the site of Conchopata in the Ayacucho valley, where married women appear to have been distinguished from unmarried ones by the latter being interred with an inverted bowl placed on their heads (Isbell and Korpisaari 2015). The ratio of 1:2 men to women, as revealed in the Conchopata funerary group, underlines the importance of gender in this population (Cook 2015, 321) and in some ways it appears to echo the later (Late Horizon) Guaman Poma reference to men having multiple wives commencing with the comparatively lesser mitimae men who were allotted two wives (Guaman Poma 1980 [1616], vol 1, 189[191], 164). The Conchopata burials have been interpreted as reflecting polygyny on the part of Wari elite males (Isbell 2004). Although other middle Horizon tombs in the same area, such as from Posoqoypata, Seqllas and Marayniyoq, do not provide such a clear gender division, with the male to female ratio being more equal. For the Marayniyoq tomb the suggestion has been made that because the 50 individuals buried there were of a range of ages, that they were members of a single lineage group (Valdez et al. 2006, 682-683). The tomb constructions in the Monjachayoc sector of Huari, with their various levels and the presence of steps, have been postulated to symbolise aspects of lineage among the individuals who would have been placed in the various tomb chambers (Przadka-Giersz 2019, 203-4). 
The presence of a structured elite similar to that of the Incas having been the case for the Wari has been demonstrated by Cook in her analysis of one set of 40 and a second set of 39 turquoise figurines found at the site of Pikillacta near Cuzco. These came from two offering deposits uncovered in close proximity to each other in the elite sector of this site and 20 of the figures in each group being equipped with identical attire. The dualistic nature of this group of figurines mirrors the later dual moiety system known for the later Inca society structure. The features and attributes of these figurines convey the transformation of deceased rulers into venerated ancestors closely matching descriptions recounted in Inca ethnohistoric accounts (Cook 1992, 341-364). Each of these offerings was associated with a metal rod similar to the one found driven into the base of the offering pit found at the east gate entrance to Pikillacta (Arriola Tuni and Tesar 2011). Both of these offerings therefore, besides referencing the ruling elite ancestry, also allude to laying a formal claim to territorial rights.

Tunics worn by the Wari elite match the textile iconographic structures associated with the Inca ruling elite (Cook 1992) with very similar repeated design elements to the recurrent patterns of tokapus on elite Inca tunics. Some of these tokapus, for example the Dumbarton Oaks elite Inca tunic, display information encoded in their devices (D'Altroy 2015, 426 plate 13) and appear to duplicate tokapu designs found in less complex configurations and fewer variations on what appear to be lower order tunics. Such differences are similarly reflected in illustrations in the Guaman Poma (1980) manuscript and appear to reflect differentiations in hierarchical tropes. The Huari tunics both in surviving textiles and where these are depicted in a figurative context, for example as depicted on ceramics, seem to have served similar purposes.

The presence of paired male and female deities in Middle Horizon art styles, as is the case with oversize vessels from Conchopata, Pacheco and with Robles Moqo style vessels (Menzel 1968, 49-51, 55-56 ), references the fundamental base form of male-female paired duality, as this continued to be evident in the later Inca tradition and persists at present in the manifestation of paired male and female sacred mountain deities and landscape features (Williams and Nash 2006, 458).

The role of women in the context of politically significant production of maize and molle beer, commonly used while establishing relationships and ritualised exchanges of obligations in the Andes, is evident and similarly continues to the present day (Allan 2002). The control of chicha production contributed to the political importance of women (Cuéllar 2013, 153). The significance of chicha production and use for the Middle Horizon Wari has been confirmed at Moquegua (Nash 2011), and the role of women in production for the Wari state has been suggested for both Moquegua (Nash 2011) and Qoripata in Huaro (Glowacki 2002, 282). It is also relevant to emphasize women's role in textile manufacture with similarly important ritualised political connotations, with respect to ethnicity and status, and 
equally being implied in the context of depictions of the Wari elite (Cook 1992; Przadka-Giersz 2019). The key function of elite women in the production of ritually charged textiles was a source of empowerment for these women. This role of designated women in textile production continued in the Late Horizon. For the Late Horizon textiles', their ritually charged qualities materialise in the extraordinary efforts exerted by the Inca military to prevent cloth and clothing from falling in the hands of the Spanish (Murra 1980, 76).

A model in which Wari power is exercised across its extensive territory is proposed by means of direct control in regions where it met resistance or competition and alternatively with delegated authority in other regions where it met less direct resistance, where its presence was far less obvious. Its power would have been manifest in its dominance over client states, where the obligations of such states to the centre and the state were marked in the kin relations articulated in the exchanges of wives between the ruling elites.

Such an interpretation is perhaps most clearly reflected in the funerary assemblage of elite women found interred at the Castillo de Huarmey site. These women have been inferred as belonging to the principal elite of the Wari state and possibly themselves related to the rulers of this elite (Makowski 2014, 317; PrzadkaGiersz 2019).

The principal burial chamber at this site included at least four distinct funerary contexts with 64 individuals. The antechamber held a number of cavities with ceramic vessels and the bodies of two seated individuals both missing their left foot, in shallow graves partially excavated into the underlying bedrock; there was a group of four small quadrangular chambers that appear to have served as a type of ossuary with the remains of at least five individuals, and animal bone as well as other materials (Giersz and Pardo 2014).

Following the placement of the 58 primary burials in the main funerary chamber, six additional bodies appear to have been placed later and these most probably represent sacrificed individuals. The primary burials were all in a flexed or seated position (Giersz and Pardo 2014).

Three smaller sub-chambers on the northeast side of the main chamber contained the remains of four women with the most north-eastern holding an adult woman and a teenager with the other two spaces both containing single adult women. These bodies were accompanied by over 1,300 opulent grave goods made of metal, wood, stone, shell and bone, comprising personal ornaments, weapons, musical instruments, weaving tools and ceramic, metal and carved stone vessels (Giersz and Pardo 2014). The varied nature and richness of this assemblage demonstrates that these women had access to a wide range of resources across either kin-based or intercommunity exchange networks (Przadka-Giersz 2019, 225).

Of the 58 women found entombed in the elite burial group at Castillo de Huarmey, the majority were young adults with a smaller group of middle to older 
adults, accompanied by a smaller group of probably also female adolescents who were sacrificed, with the elite women exhibiting little or no evidence of physiological stress, disease, or violence in their physical remains (Giersz 2016, 238, 245; Knudson et al 2017,252), although there was some evidence of some temporary stress in childhood in the form of pathological lesions (Giersz 2017, 191). Signs of osteoporosis in a number of these individuals may be indicative of repetitive activities, such as those associated with textile production, which may be supported by the large assemblage of artefacts related to textile weaving and spinning, associated with the assemblage, although a genetic predisposition to the condition could also be responsible (Giersz 2017, 191). Clearly, this evident link between women and textile production, also visible in women in an elite context, mirrors what is known about this activity with respect to the lives of high-status women during the Late Horizon (Przadka-Giersz 2019). Textiles were essential to expressing status and identity. The transfer of craft skills by the gifting of women facilitated the production of the very elite goods which were central to Wari status and religious practice (Isbell 2007; Nash 2019).

The associated insect remains, in particular the presence of fly pupae and beetles and snakes and their eggs from within the interments and mummy bundles at Castillo de Huarmey, confirms that these elite women were not interred in a single event but that the burials occurred over a period of time. The final act of the process of interment being the ritual sacrifice of the six adolescents (Giersz 2016, 245), including a seated male and female, both with their left feet amputated in one of the antechambers to this elite mausoleum. These have been interpreted as guardians of the tomb and were evidently not part of the elite population, as was also confirmed in evidence relating to their state of health, which proved these two led significantly more stressful lives than the other individuals within the tomb (Giersz 2016, 246; Knudson et al 2017, 252).

Several of the individuals from the Castillo de Huarmey mausoleum appear to have arrived in the tomb already in a mummified state (Przadka-Giersz $2019,216)$. Similarly, the movement of mummified remains between tombs has been identified by Jennings and Yepez at the Middle Horizon site of Tenahaha in Cotahuasi Valley in the department of Arequipa (Jennings 2015b, 204-5; Kellner et al. 2015, 190). This suggests that, as with Inca principal elite individuals, these mummified remains had been deployed in activities with the living for some time prior to their ultimate placement in their tombs.

It is evident that the concept of ancestor worship was as an important aspect of funerary ritual at Castillo de Huarmey with the principal elite adult female burials in the mausoleum (Prządka-Giersz and Giersz 2013-14, 131). This further confirms that women played a principal role in elite descent and kinship structures. The fact that the treatment of elite women in death in a manner befitting their status was not limited to a Middle Horizon coastal context is confirmed in burial evidence from Ancash and the northern highlands (Przadka-Giersz 2014, 102). 
An interesting detail of the funerary assemblages of four of the chief elite female individuals from the Castillo de Huarmey mausoleum is that these included earplugs (Przadka Giersz 2014, 105-126, 150-159). Such items of personal adornment for the Late Horizon Inca have been particularly attributed to elite males. However, at Castillo de Huarmey there were over one hundred earplugs in gold, silver, bone and wood, of which a number were inlaid with other materials. These earplugs were either located around the position of the ears of the elite women or found stored in baskets (Giersz 2017, 199). Another such finding is known from a Recuay elite burial of a female individual from Pasash, where the burial was directly associated with such ear ornaments (Castro de la Mata, and Velarde, 2008 263-264). It remains unclear whether in these contexts such ornaments designate male qualities or whether they reflect status or both. Indeed, within such funerary settings it may be the engendered supernatural aspects of the individuals which is being accentuated.

The fact that three of the four women in the Castillo Huarmey Mausoleum who constituted the principal burials among the funerary group were all older or middle-aged adults indicates that upper elite post-menopausal women retained their status and prominence in Wari society. This continued reverence for aging females of high status is identical to what is known from Late Horizon Inca upper elite contexts. The mothers of Huayna Capac, Huascar and Atahualpa, for example, carried considerable political weight and importance as evident in the way they are referred to in various chronicle sources. Also, the existence of senior female community leaders of kuraka rank is manifest in the same source material (Przadka Giersz 2014, 103; Rostworowski 1988, 12-13). In the panacas of the Inca where mummified remains of ancestral Inca rulers were maintained by continuing use of the estates the ruler had laid claim to in life, senior surviving wives of such rulers exercised considerable political power (Rostworowski 1988, 11-12).

From the perspective of the hypothesis that the exchange and gifting of elite wives was a fundamental aspect of the Wari state power network, the group of elite women excavated at the site of the Castillo de Huarmey offered an opportunity to test this hypothesis. If the highland Wari elite provided the contemporary Huarmey elite with high status wives from the Wari heartland, then the biochemistry samples from the Castillo de Huarmey group should provide clear evidence for this.

From isotope analysis, the group of elite women proved to have similar origins. Of the 38 individuals for whom the Strontium Isotopic data was tested, the ${ }^{87} \mathrm{Sr} /{ }^{86} \mathrm{Sr}$ ratio confirmed a signature compatible with a first- or second-generation local origin or from potentially elsewhere along the north or central coast (Knudson et al 2017; Więckowski 2019, 97-102; 129-130). What was noticeable was that the diet of the majority appeared more terrestrial than coastal than was the case for contemporary locals. The aDNA results of 15 individuals were compatible with a relationship with populations further south along the coast, most similar to Middle Horizon samples from the Huaca Pucllana in Lima (Giersz 2017, 191; Więckowski 
$2019,102)$. It is therefore possible that these individuals originated from the central or south coast.

This therefore indicates that in this instance a group of high-status women, who were raised along the coast but had a taste for highland foods and were closely related to the central or south coastal populations, were placed in the Castillo de Huarmey high status tomb, accompanying a very high-status individual with similar tastes and origins.

This suggest that an elite group of women, who were culturally and genetically distinct from the local population, filled the niche of elite wives within the local ruling class, indicating that other groups were also involved in marriage exchange and that the Wari were not always the dominant player. This likewise confirms that a form of control was exercised with respect to who married whom within this population. While the latter is perhaps not surprising, it would also allow for variants of the model of Wari rulers exercising such control to have been operating.

The shift from individual to multiple burials, which takes place from the Early Intermediate Period to the Middle Horizon, is indicative of a change in perception of kinship structures (Makowski and Giersz 2016, 24 -25). The presence of female deities in the Middle Horizon religious repertoire (Makowski and Giersz 2016, 30) confirms that Middle Horizon perceptions of cosmology rendered substance to both male and female aspects of their ideology.

Potentially the death of the leader and/or the death of their principal wife could lead to a disruption in an inter-state alliance, formed through the marriage engendered kin relationship. However, the fact that elite burials are extremely elaborate and show clear evidence of a shared approach to the burial process suggests that the status of the deceased continued to be recognised after their death. The offering of sacrifices and libations could attest to the continuity of established social relationships with ancestors - something that would be worked out and reinforced at the moment of the burial rituals.

At La Real in the Majes Valley, from where a Wari Middle Horizon group of human remains was analysed, it was clear that physiological stress resulting from malnutrition, anaemia or infections where evident in these remains was similar for men and women across this population (Yépez Álvarez et al 2016, 158). However, trauma resulting from acts of violence was significantly lower for the females in this population where $41 \%$ of males as opposed to $19 \%$ of women showed evidence for such damage (Idem, 154).

Other biochemistry evidence from a Middle Horizon, Tiahuanaco rather than Wari cemetery at Chen in the Moquegua valley manifested evidence in the strontium isotopic signature of some of the females in this group. This demonstrated these women moved here from the Lake Titicaca area, a pattern which is repeated in the analogous San Pedro de Atacama funerary groups (Knudson 2008, 16). Again, of Middle Horizon date, but from a mortuary population including burials associ- 
ated with Tiahuanaco influences, strontium isotope data from the San Pedro de Atacama cemetery groups indicate the presence of a limited number of individuals, both male and female, with origins from the vicinity of Lake Titicaca. The burial characteristics and grave goods of these persons do not exhibit status or social differentiation to set them apart from the general cemetery population (Knudson and Torres-Rouff 2014). A woman from a Middle Horizon period elite tomb complex at La Tiza in the Nasca valley has a strontium isotope signature indicative of a highland, probably Cuzco area origin (Conlee 2011, 52).

Isbell argued that the ideal Inca ayllu concept of ayllu endogamy and sister exchange is reflected in Late Intermediate Period chullpa characteristics, with specific reference to the chullpas of Chota-Cutervo (Isbell 1997, 214-283) and that this ideal form features four levels and four sides, 'corresponding to four generations and four kin groups' (Isbell 1997, 279). In this context, the fact that the two elite royal megalithic subterranean tomb complexes excavated at Huari have four levels and four sides (Perez Calderon 1999, 55) suggests that such an ayllu model may have been adhered to by upper levels of the Wari elite.

The expression of imperial ideology, expansion and control of the Wari state and that of the late Inca empire shared many characteristics, as they both were based on an imperial cult and concepts of Andean reciprocity and included interelite alliances and interlinking religious with military power (Giersz and Makowski 2014, 57-60, Przadka-Giersz 2019, 228-9).

Therefore, the notion that Middle Horizon ideal kin structures were similar to Late Horizon Inca ones indicates that the political management of women in marriage arrangements as secondary wives in the expansive attributes of the Wari conquest state followed similar paths to those employed later by the Inca elite.

\section{The end of empire}

The collapse of the Huari imperial influence and control manifests itself in various ways across its former domain. In the Cusco area, despite the abandonment of its principal administrative centre, a total abandonment of elite and hierarchical structures appears not to have taken place. Major sites with large public buildings continued to develop, for example the site of Chokepukio. Similarly, high-quality elite-type ceramics continued to be produced in the Killke and Lucre pottery styles, characteristic of the region. Similar developments, where a regional elite fills the tier abandoned by the Wari imperial class, have been identified in the Moquegua, Cotahuasi, and Chicha Soras valleys (Jennings and Yépez 2001; Meddens and Vivanco 1018; Sharratt 2019), the Cajamarca area, as well as along much of the coastal area and elsewhere. The changes observed for the Late Intermediate Period across the area formerly controlled by Wari vary from place to place. They include demographic shifts, increased evidence for regional conflict, technological changes, including in some areas such as 
parts of Ayacucho, Apurimac and Huancavelica, a rapid reduction in technological complexity accompanied by the disappearance of elite hierarchical structures (Meddens and Vivanco 1018). The continuity of hierarchical elite structures, evidence for ancestor worship and complex state mechanisms in some parts of the former Wari empire facilitated the continuity of such mechanisms into the late Inca state and their deployment in the rule and control of its empire.

\section{Conclusions}

The archaeological evidence for the structure of the Wari state and its organisation and development includes all characteristics to be expected of an empire. These include a hierarchical structure, a strong coercive military element, an expressive and formal ideology manifest in a defined symbolism visible in its modes of dress and adornment, formal ceramic, sculptural and architectural styles and religious and funerary traditions. Like the later Inca empire, its administrative presence is manifest in a strongly symbolic structure of asymmetrical public generosity. Evidence for a state record keeping institution is evident in the identification of Wari quipu use (Conklin 1982; Urton 2014). The Wari presence is most strongly marked in areas where its state architecture can be recognised, e.g. rectangular enclosures with modular patio and gallery divisions and D-shaped temples. These would be the areas under direct central control or in a close proximity of such jurisdiction. Areas where its rule would have been more subtle were client states. The empire depended on the subordinance of the local ruling elite to conform to its will. These regional elites were integrated into the power structures of the state by the establishment of kinship links, ayllu and moiety structures and the traditional rules, duties and obligations associated with these. This was achieved by means of the exchange and gifting of women as wives for members of ruling elites. This tradition can be observed in the acceptance of Wari ideology and symbols by regional elites, as apparent in iconography, in dress and artefact styles. The adoption of new burial practices was directly related to the institution of new kin structures between the elite at the centre and its subordinate regional counterparts. The social significance of death by its potential to sever the relationships between elites is addressed in the identified funerary traditions. The complexity of burials and evidence for shared burial practices indicate that the status of the deceased continued to be recognised after death. The offering of sacrifices attests to the endurance of this relationship through ancestors, reinforced in the burial rituals. Such a model for Wari as an empire would match the emerging patterns for the end of the empire. The loss of control at the dominant centre of Huari had disparate effects across the area of the empire, where local elites had varying levels of success in maintaining their regional authority.

The elite women gifted to the ruling elites of client polities would have commanded authority in their own right. They would have been empowered not only by the kin links they embodied and the offspring they brought into being, but also 
as active agents by their control of the production of certain ritually charged goods, such as categories of textiles and chicha (Isbell 2007; Nash 2019).

The bioarchaeological studies to date, particularly from Huarmey and La Tiza, provide support for a model in which women exchange and gifting was part of the political instruments deployed by the Wari leadership in their efforts to manage their expanding empire.

The striking similarities between Wari and Inca kin structures suggest the existence of a similar ayllu and moiety model and an equivalent role for high-ranking women as powerful individuals within the ruling elite. The evidence favours the notion that women eligible for marriage were deployed in an analogous manner to that known for the Late Horizon Inca.

\section{Acknowledgements}

I am grateful to Professor Mariusz Ziółkowski for encouraging me to write this article, to Michał Gilewski for guiding it through to publication, and to Kevin Lane, Bill Sillar, and to two anonymous peer reviewers for their very helpful comments on previous versions of this paper and to Agnieszka Hamann for her text corrections.

\section{References}

Allen, Catherine, J.

2002 The Hold Life Has: Coca and Cultural Identity in an Andean Community. Smithsonian Institution Press, Washington.

Anders, Martha B.

1986 Dual Organisation and Calendars inferred from the Planned site of Azangaro-Wari, Administrative Strategies, Volume 1-3. PhD dissertation Cornell University.

Andrushko, Valerie A., Buzon, Michele R., Simonetti, Antonio and Creaser, Robert A.

2009 Strontium Isotope Evidence for Prehistoric Migration at Chokepukio, Valley of Cuzco, Peru. Latin American Antiquity, 20 (1): 57-75. https://doi.org/10.1017/S1045663500002510

Arriola Tuni, Carlos A. and Tesar, Louis D. 2011 The Pikillacta

2004 Eastern Gate Offering Pit, Nawpa Pacha, Journal of Andean Archaeology 31 (1): 1-44.

https://doi.org/10.1179/naw.2011.31.1.1

Baca, Mateusz, Doan, Karolina, Sobczyk, Maciej, Stankovic, Anna and Piotr Węgleński

2012 Ancient DNA reveals kinship burial patterns of a pre-Columbian Andean community. Genetics 13:30. https://doi.org/10.1186/1471-2156-13-30

Bejar Navarro, Raymundo

1990 Arquitectura Inka, El Templo del Sol o Qorikancha, Imprenta Yañez Cusco. 
Bennett, Wendell C.

1953 Excavations at Wari, Ayacucho, Peru, Yale University Publications in Anthropology, 49, New Haven.

Bélisle, Véronique

2015 Understanding Wari State Expansion: a "bottom-up" approach at the village of Akawillay, Cusco, Peru. Latin American Antiquity 26 (2): 180-199.

https://doi.org/10.7183/1045-6635.26.2.180

Benavides C., Mario

1991 Cheqo Wasi, Huari, In Huari Administrative Structure, Prehistoric Monumental Architecture and State Government edited by William H. Isbell and Gordon McEwan (Eds), pp. ., 55-69, Dumbarton Oaks, Washington D.C.

Bragayrac D., Enrique

1991 Archaeological Excavations in the Vegachayoc Moqo Sector of Huari, In Huari Administrative Structure, Prehistoric Monumental Architecture and State Government, edited by William H. Isbell and Gordon McEwan, pp. 71-80, Dumbarton Oaks, Washington D.C..

Castro de la Mata, Pamela, y María Inés Velarde

2008 "La tumba de una mujer de elite Recuay", In Señores de los Reinos de la Luna, edited by Krzysztof Makowski, Joanne Pillsbury, Régulo G. Franco Jordán, pp. 262-265, Banco de Crédito del Perú.

Conklin, William J.

1982 The information system of the Middle Horizon quipus, In Ethnoastronomy and Archaeoastronomy in the American Tropics. pp. 261-281. New York: New York Academy of Sciences.

Conlee, Christina A.

2010 Nasca and Wari: Local Opportunism and Colonial Ties during the Middle Horizon, In: Beyond Wari Walls: Regional Perspectives on Middle Horizon Peru, edited by Justin Jennings (Ed) pp. 96-109, University of New Mexico Press, Albuquerque

2011 An exploration of looted Middle Horizon tombs from Nasca, Nawpa Pacha: Journal of Andean Archaeology, 31 (1): 45-54.

Cook, Anita G.

1992 The Stone Ancestors: Idioms of Imperial Attire and Rank among Huari Figurines, Latin American Antiquity, Vol. 3, No. 4: 341-364.

2015 The Shape of Things to Come: The Genesis of Wari Wak'as, In The archaeology of wak'as : explorations of the sacred in the pre-Columbian Andes, edited by Bray, Tamara L., pp. 295-334, University Press of Colorado,. 
Cook, Anita G. and Glowacki, Mary

2003 Pots, politics, and power: Huari ceramic assemblages and imperial administration, In The Archaeology and Politics of Food and Feasting in Early States and Empires, edited by Tamara Bray, pp. 173-202, Kluwer Academic/Plenum Publishers, Springer, Boston, MA,.

Cuéllar, Andrea M.

2013 The Archaeology of Food and Social Inequality in the Andes, Journal of Archaeological Research, 21 (2): 123-174.

D'Altroy, Terence N.

2015 The Incas, Wiley Blackwell.

Edwards, Matthew J. and Schreiber, Katharina

2014 Pataraya: The Archaeology of a Wari Outpost in Nasca, Latin American Antiquity, 25 (2), 215-233. https://doi.org/10.7183/1045-6635 .25.2.215

Farrington, Ian

2013 Cusco Urbanism and Archaeology in the Inka World, University Press of Florida.

Fonseca Santa Cruz, Javier and Bauer, Brian S.,

2013 Dating the Wari Remains at Espiritu Pampa, Vilcabamba, Cusco, Andean Past 11, (12), 111-121.

Garcilaso de la Vega, Inca

1723 [1609] Primera Parte de los Commentarios Reales que tratan, de el Origen de los Inkas, Reies, que fueron del Peru de su Idolatria, Leies, y Gobierno, en Paz, y en Guerra, de sus Vidas, y Conquistas, $y$ de todo lo que fue en Giersz, Miłosz aquel Imperio, Madrid.

2016 Castillo de Huarmey: centro político wari en la costa norte del Perú, Andes, Boletín del Centro de Estudios Precolombinos de la Universidad de Varsovia 9: 217-262.

2017 Castillo de Huarmey un Centro del Imperio Wari en la Costa Norte del Perú, Ediciones del Hipocampo.

Giersz, Milosz and Makowski, Krzysztof

2014 El fenómeno Wari: tras las huellas de un imperio prehispánico In Castillo de Huarmey el Mausoleo Imperial Wari edited by Milosz Giersz and Cecilia Pardo, Asociación Museo de Arte de Lima, 35-67.

Giersz, Milosz and Pardo, Cecilia

2014 Castillo de Huarmey, el Mausoleo Imperial Wari, El Museo de Arte de Lima - MALI.

Glowacki, Mary

2002 The Huaro Archaeological Site Complex: Rethinking the Wari Occupation of Cuzco, In Andean Archaeology edited by W. H. Isbell and H. 
Silverman, pp. 267-285, Kluwer Academic/Plenum Publishers, New York.

Glowacki, Mary and Malpass, Michael

2003 Water, Huacas, and Ancestor Worship: Traces of a Sacred Wari Landscape, Latin American Antiquity, 14, (4): 431-448. https://doi. org $/ 10.2307 / 3557577$

Glowacki, Mary and McEwan, Gordon

2001 Pikillacta, Huaro and the Greater Cuzco Region: New Interpretations of Wari Occupation in the Southern Highlands, Boletin de Arqueología PUCP 5 (31).

Glowacki, Mary and Zapata, Julinho

1998 The Wari Occupation of Cuzco: Recent Discoveries from the Huaro Valley. Paper Presented at the 38th Annual Meeting of the Institute of Andean Studies, Berkeley.

Guaman Poma de Ayala, Felipe (Waman Puma)

1980 [1583-1615] El Primer Nueva Coronica y Buen Gobierno edited by Murra John, V., Rolena Adorno and Jorge, L. Urioste 3 vols. Siglo Veintiuno, América Nuestra, México.

Hernández Astete, Francisco

2012 Los Incas y el Poder de sus Ancestros, PUCP, Lima.

Isbell, William H.

1977 The Rural Foundation for Urbanism: Economic and Stylistic Interaction between Rural and Urban Communities in Eight-Century Peru, University of Illinois Press, Urbana.

1989 Honcopampa: was it a Huari administrative Centre. In The Nature of Wari, a reappraisal of the Middle Horizon Period in Peru edited by R.M. Czwarno, FM Meddens and A. Morgan, BAR 525 Oxford, 98-114.

1997 Mummies and mortuary monuments: a Postprocessual prehistory of Central Andean social organization, Austin: University Texas Press.

2004 Mortuary Preferences: A Wari Culture Case Study from Middle Horizon Peru, Latin American Antiquity 15 (1): 3-32. https://doi. org/10.2307/4141562

2007 A community of potters or multicrafting wives of polygynous lords? In Craft production in complex societies: Multicraft and producer perspectives edited by Izumi Shimada University of Utah Press, Salt Lake City, 68-96.

2010 Agency, Identity, and Control: Understanding Wari Space and Power. In Beyond Wari Walls Regional Perspectives on Middle Horizon Peru, edited by Jennings, Justin pp. 233-254. University of New Mexico Press. Albuquerque. 
Isbell, William H., Brewster-Wray, Christine, Spickard Lynda E.

1991 Architecture and Spatial Organisation at Huari. In Huari Administrative Structure, Prehistoric Monumental Architecture and State Government, pp. 19-53 Dumbarton Oaks, Washington D.C.

Isbell, William, H. and Anita Cook

2002 New perspective on Conchopata and the Andean Middle Horizon. In Andean archaeology II: Art, Landscape, and Society edited by William Isbell and Helaine Silverman, pp. 249-305. Kluwer Academic / Plenum Publishers, New York.

Isbell, William H. and Antti Korpisaari

2015 Bodies of Evidence, Mortuary Archaeology and the Wari Tiwanaku Paradox. In Funerary Practices and Models in the Ancient Andes, Return of the Living dead, edited by Peter Eeckhout and Lawrence S. Owens, pp.137-157. Cambridge University Press, New York.

Isbell, William H. and Schreiber, Katharina J.

1978 Was Huari a State? American Antiquity, 43 (3) 372-389. Jennings, Justin

2010 Becoming Wari: Globalization and the Role of the Wari State in the Cotahuasi Valley of Southern Peru. In Beyond Wari Walls: Regional Perspectives on Middle Horizon Peru, pp. 37-56 in: edited by Peter Eeckhout and Lawrence S. Owens, University of New Mexico Press. Albuquerque.

2015a An Introduction to the Tenehaha Site. In Tenahaha and the Wari state. A view of the Middle Horizon from the Cotahuasi Valley, edited by Jennings, Justin and Yepez, Willy J, pp.16-47, The University of Alabama Press, Tuscaloosa.

2015b Tenahaha and the Wari state. A view of the Middle Horizon from the Cotahuasi Valley. In Tenahaha, Wari and Middle Horizon Peru, edited by Jennings, Justin and Yepez, Willy J,, pp. 199-212. The University of Alabama Press, Tuscaloosa.

Jennings, Justin and Yépez Álvarez, Willy

2001 Architecture, Local Elites, and Imperial Entanglements: The Wari Empire and the Cotahuasi Valley of Peru, Journal of Field Archaeology, 28 (1/2): 143-159.

Jennings, Justin and Yépez Álvarez, Willy (editors)

2015 Tenahaha and the Wari state. A view of the Middle Horizon from the Cotahuasi Valley, The University of Alabama Press, Tuscaloosa.

Kellner, Corina M., Mummert, Amanda, Palma Malaga, Matha, Mora, Franco and Guadalupe Ochoa

2015 Bioarchaeological Analysis of the Tenahaha Tombs. In Tenahaha and the Wari state. A view of the Middle Horizon from the Cotahuasi Valley, 
edited by Jennings, Justin and Yepez, Willy J, pp. 181-198. The University of Alabama Press, Tuscaloosa.

Kerchusky, Sarah Lorraine

2018 Archaeological Investigations at Zorropata: Local Socioeconomic and Political Development, UC Santa Barbara Electronic Theses and Dissertations.

Knudson, Kelly J.

2008 Tiwanaku Influence in the South-Central Andes: Strontium Isotope Analysis and Middle Horizon Migration, Latin American Antiquity, 19 (1): 3-23. https://doi.org/10.1017/S104566350000763X

Knudson, Kelly J., Giersz, Miłosz, Więckowski, Wiesław, Tomczyk, Weronika

2017 Reconstructing the lives of Wari elites: Paleomobility and paleodiet at the archaeological site of Castillo de Huarmey, Peru, Journal of Archaeological Science: Reports 13: 249-264. https://doi.org/10.1016/j. jasrep.2017.03.047

Knudson, Kelly J. and Torres-Rouff, Christina

2014 Cultural Diversity and Paleomobility in the Andean Middle Horizon: Radiogenic Strontium Isotope Analyses in the San Pedro de Atacama Oases of Northern Chile, Latin American Antiquity, 25, (2), 170-188. https://doi.org/10.7183/1045-6635.25.2.170

Kolata, Alan L.

1993 The Tiwanaku: Portrait of an Andean Civilization, Alan Kolata and Dean Snow (Eds) The Peoples of America Series, Blackwell Cambridge \& Oxford.

Landeo Lapa, Javier

2010 La Presencia de Huari en la Cuenca Media e Inferior del Rio Huarpa: Contextualizando desde la Prospección, Universidad de San Cristóbal de Huamanga, Facultad de Ciencias Sociales Escuela de Formación Professional de Arqueologia e Historia, unpublished dissertation. Lau, George F.

2011 Andean Expressions, Art and Archaeology of the Requay Culture, The Iowa Series in Andean Studies, The University of Iowa Press, Iowa City.

Lounsbury, Floyd G.

1978 Aspects du système de parenté inca, Annales. Histoire, Sciences Sociales, 33e Année, No. 5/6, Anthropologie Historique des Sociétés Andines, 990-1005.

Lumbreras, Luis G.

1974 Las Fundaciones de Huamanga. Hacia una Prehistoria de Ayacucho. Editorial “Nueva Educación”, Lima. 
Makowski, K.

2014 Elites imperiales y símbolos del poder, in: Castillo de Huarmey. El mausoleo imperial wari, LIMA. Museo de Arte de Lima, 189 - 208.

Makowski, Krzysztof y Giersz, Miłosz

2016 El Imperio en debate: hacia nuevas perspectivas en la organización política Wari, Andes. Boletín del Centro de Estudios Precolombinos, de la Universidad de Varsovia 9: 5-37.

Mallco Huarcaya, Rafael

2013 Ocupación Prehispanica en el área del distrito de San Pedro de Larcay, Sucre - Ayacucho. Arqueología y Sociedad 25: 215-258

Mallco Huarcaya, Rafael and Angulo Paredes, Luis

2016 Desarrollo Cultural y Principales Características Arquitectónicas en los Sitios Prehispánicos del Distrito de San Pedro de Larcay, Provincia Sucre, Departamento Ayacucho. Arqueología y Sociedad, 32: 57-110.

Malpass, Michael., Puglisi, Anthony and Kerschner, Jason

1997 Wari on the Far South Coast of Peru: The Site of Sonay in the Camana Valley. Paper presented at the 62nd Annual Meeting of the Society for American Archaeology, Nashville.

McEwan, Gordon (Editor)

2005 Pikillacta: The Wari Empire in Cuzco, University of Iowa Press, Iowa City.

McEwan, Gordon, F., M. Chatfield and A. Gibaja

2002 The Archaeology of Inca Origins. Excavations at Chokepukio, Cuzco, Peru, iIn Andean Archaeology I. Variations in Sociopolitical Organization, edited by W. H. Isbell y H. Silverman, pp. 287-301, Kluwer Academic/ Plenum Publishers, New York,

Meddens, Frank M.

1985 The Chicha/Soras Valley during The Middle Horizon: Provincial Aspects of Huari. Unpublished Ph.D. dissertation, Institute of Archaeology, University of London.

1991 A Provincial Perspective of Huari Organisation Viewed from the Chicha/Soras Valley. In Huari Administrative Structure; Prehistoric Monumental Architecture and State Government, edited by William H. Isbell and Gordon McEwan Dumbarton Oaks, pp. 215-231. Washington, D.C.

Meddens, Frank M. and Nicholas Branch

2010 The Wari State, Its Use of Ancestors, Rural Hinterland, and Agricultural Infrastructure. In Beyond Wari Walls, Regional Perspectives on Middle Horizon Peru, edited by Justin Jennings, pp. 155-170. University of New Mexico Press, Albuquerque. 
Meddens, Frank M., and Anita Cook

2000

La administración Wari y el culto a los muertos: Yako, los edificios en forma "D" en la sierra sur-central del Peru. In Wari: Arte Precolombino Peruano, edited by Luis Millones, pp. 212-228. Fundación El Monte, Seville.

Meddens, Frank M., Colin McEwan, and Cirilo Vivanco Pomacanchari

2010 Inca "Stone Ancestors" in Context at a High-Altitude Usnu Platform, LatinAmericanAntiquity21 (2):173-194.https://doi.org/10.7183/10456635.21.2.173

Meddens, Frank M. and Cirilo Vivanco Pomacanchari

2018 The late Intermediate Period ceramic traditions of Ayacucho, Apurimac and Huancavelica: current thoughts on the Chanca and other regional polities, Nawpa Pacha, Journal of Andean Archaeology 38: 3-56. https://doi.org/10.1080/00776297.2018.1436653

Menzel, Dorothy

1964 Style and Time in the Middle Horizon, Nawpa Pacha, Journal of Andean Archaeology, 2:1, 1-105.

1968 New Data on the Huari Empire in Middle Horizon Epoch 2A, Nawpa Pacha: Journal of Andean Archaeology, 6, 47-114.

Moseley, Michael, E., R. A. Feldman, P. S. Goldstein y L. Watanabe

1991 Colonies and Conquest: Tiahuanaco and Huari in Moquegua, In Huari Administrative Structure: Prehistoric Monumental Architecture and State Government, Dumbarton Oaks Research Library and Collection edited by W. H. Isbell y G. F. McEwan, pp. 93-119, Washington, D.C.

Murra, John

1980 The Economic Organization of the Inka State, JAI Press, Greenwich. Nash, Donna J.

2011 Fiestas y la economía política Wari en Moquegua, Perú / Feasting and the Wari Political Economy in Moquegua, Peru, Chungara: Revista de Antropología Chilena, 43, (2): 221-242.

2019 Craft Production as an Empowering Strategy in an Emerging Empire, Journal of Anthropological Research, 75 (3): 328-60. https://doi. org/10.1086/704144

Protzen, Jean-Pierre

1993 Inca Architecture and Construction at Ollantaytambo, Oxford University Press, Oxford.

Pérez Calderón, Ismael

1999 Huari; Misteriosa Ciudad de Piedra, Universidad Nacional San Cristóbal de Huamanga. 
Przadka Giersz, Patrycja

2014 Ajuar personal: las mujeres de la élite wari y su atuendo, In Castillo de Huarmey el Mausoleo Imperial Wari, edited by Milosz Giersz and Cecilia Pardo, pp. 101-128, Asociación Museo de Arte de Lima.

2019 Mujer, poder y riqueza. La Tumba de elite femenina Wari del Castillo de Huarmey, Ediciones del Hipocampo SAC, Lima.

Prządka-Giersz, Patrycja and Giersz, Miłosz

2014 Sociopolitical transformations during the late pre-Hispanic times as revealed by the archaeological, record from the Culebras Valley, north coast of Peru, Estudios Latinoamericanos Revista de la Sociedad Polaca de Estudios Latinoamericanos, Vol. 33/34: 125-150. https://doi. org/10.36447/Estudios2014.v33-34.art5

Rostworowski, María

1988 La Mujer en la época prehispánica, Documento de Trabajo N ${ }^{0}$ 17, Instituto de Estudios Peruanos.

Sarmiento de Gamboa

1988 [1572] Historia de los Incas, Miraguano Ediciones, Ediciones Polifemo, Madrid.

Schreiber, Katharina J.

1987 Conquest and Consolidation: A Comparison of the Wari and Inka Occupations of a Highland Peruvian Valley, American Antiquity, 52 (2): 266-284.

1992 Wari Imperialism in Middle Horizon Peru, Anthropological Papers, No. 87. Ann Arbor: Museum of Anthropology, University of Michigan.

2004 Sacred Landscapes and Imperial Ideologies: The Wari Empire in Sondondo, Peru, Archaeological Papers of the American Anthropological Association, 14: 131-150. https://doi.org/10.1525/ap3a.2004.14.131

2005 Imperial Agendas and Local Agency, In The Archaeology of Colonial Encounters: Comparative Perspectives, edited by Gil J. Stein, School of American Research, Santa Fe, 237-262.

2012

The Rise of an Andean Empire, In Wari Lords of the Ancient Andes. edited Sharratt, Nicola by Susan E. Bergh, pp. 32-45, Thames and Hudson, New York, 31-45.

2019 Tiwanaku's Legacy: A Chronological Reassessment of the Terminal Middle Horizon in the Moquegua Valley, Peru, Latin American Antiquity, 30 (3): 529-549. https://doi.org/10.1017/laq.2019.39

Shady, Ruth

1988a La época Huari como interacción de las sociedades regionales. Revista Andina. 6(1): 67-99. With comments by M. Anders, B. Bauer, W. Isbell, L. Lumbreras, R. Matos, G. McEwan, M. Moseley and D. Pozzi-Escot: 100-120. Response by Shady: 121-133. 
1988b La Interacción Regional Durante la Época Huari, In Simposium Arquitectura y Arqueología. Pasado y Futuro de la Construcción en el Perú, pp. 87-96, edited by Rangel, Víctor CONCYTEC. Trujillo.

Sillar, Bill, Dean, Emily and Amelia Pérez Trujillo

2013 My State or yours? Wari "Labor Camps" and the Inka Cult of Viracocha at Raqchi, Cuzco, Peru, Latin American Antiquity 24 (1): 21-46. https://doi.org/10.7183/1045-6635.24.1.21

Silverblatt, Irene

1987 Moon, Sun and Witches, Gender Ideologies and Class in Inca and Colonial Peru, Princeton University Press, New Jersey.

Spickard, Lynda E.

1983 The Development of Huari Administrative Architecture, In Investigations of the Andean Past, edited by Daniel H. Sandweiss, pp. 136-160, Latin American Studies Program, Cornell University.

Tantaleán, Henry

2014 Un Estado Militarista Andino llamado Wari: hacia una definición Ar-

Tello, Julio C. queológica, Investigación 22 (2).

1931 [1970] Las Ruinas de Huari, In 100 años de Arqueología en el Perú, edited by Ravines, Rogger, pp.519-525. IEP/Petróleos del Perú. Lima.

2002 Arqueología de la Cuenca del Río Grande de Nasca In Cuadernos de Investigación del Archivo Tello, No. 3, edited by P. Novoa Bellota, Museo de Arqueología y Antropología de la Universidad Nacional Mayor de San Marcos, Lima.

Toohey, Jason L.

2011 Formal and stylistic variation in the ceramic assemblage at the Late Intermediate Period site of Yanaorco in the Cajamarca highlands of northern Peru, Nawpa Pacha: Journal of Andean Archaeology, 31 (2):171-199.

Topic, John. R.

1986 A Sequence of Monumental Architecture from Huamachuco, In Perspectives on Andean Prehistory and Protohistory, edited by D. H. Sandweiss y D. P. Kvietok, , pp.63-83, Latin American Studies Program, Cornell University, Ithaca.

1991 Huari and Huamachuco, In Huari Administrative Structure: Prehistoric Monumental Architecture and State Government, edited by D. H. Sandweiss y D. P. Kvietok, pp.164-194, Dumbarton Oaks Research Library and Collection, Washington, D.C.

Topic, John R. and Theresa Lange Topic

2000 Hacia la Comprensión del Fenómeno Huari: una Perspectiva Norteña, Boletín de Arqueologia PUCP 4: 181-217. 
Urton, Gary

2014 Dos Kiphus Wari del Horizonte Medio provenientes de Castillo de Huarmey, In Castillo de Huarmey, El Mausoleo Imperial Wari edited by Milosz Giersz, Cecilia Pardo, pp. 251-7, LIMA. Museo de Arte de Lima,.

Valdez, Lidio M., Bettcher, Katrina J., Ochatoma José A. and Valdez, J. Ernesto

2006 Mortuary Preferences and Selected References: A Comment on Middle Horizon Wari Burials, World Archaeology, 38, (4): 672-689.

Więckowski, Wieslaw

2019 Wari Women from Huarmey, Bioarchaeological Interpretation of Human Remains from the Wari Elite Mausoleum at Castillo de Huarmey, Peru, Archaeopress Pre-Columbian Archaeology 11, Oxford.

Williams, Patrick Ryan

2002 Disaster-Induced Collapse in the Demise of the Andean Highland States: Wari and Tiwanaku, World Archaeology, 33 (3): 361-374.

Williams, Patrick Ryan and Nash, Donna J.

2006 Sighting the apu: A GIS Analysis of Wari Imperialism and the Worship of Mountain Peaks World Archaeology, 38 (3): 455-468.

Yépez Álvarez, Willy J., Jennings, Justin y Tung, Tiffiny A.

2016 La Real: un contexto funerario influenciado por los waris en el sur peruano, Andes, Boletín del Centro de Estudios Precolombinos de la Universidad de Varsovia 9: 121-170.

Zapata Rodríguez, Julinho

1997 Arquitectura y Contextos Funerarios Wari en Batan Urqu, Cusco, Boletín de Arqueología, PUCP, 1, 165-206.

Zevallos, María Angélica

2018 El Mito de Pilcosisa y Mama Huaco, Revista de Letras 58 (1): 49-62.

Zuidema, Reiner Tom

1977 The Inca Kinship System: A New Theoretical View, In Andean Kinship and Marriage, edited by Ralph Bolton and Enrique Mayer, pp. 248-292, Special Publication American Anthropological Association, 7.

1990 Inca Civilization in Cuzco, University of Texas Press, Austin. 
